\title{
AN EMPIRICAL STUDY OF THE RELATIONSHIPS BETWEEN THE FLEXIBLE WORK SYSTEMS (FWS), ORGANIZATIONAL COMMITMENT (OC), WORK LIFE BALANCE (WLB) AND JOB SATISFACTION (JS) FOR THE TEACHING STAFF IN THE UNITED ARAB EMIRATES (UAE)
}

\author{
Vijay Kumar Gudep \\ City University College of Ajman, UAE
}

\begin{abstract}
The research study examines the relationships between the flexible work systems (FWS), organizational commitment (OC), work life balance (WLB) and job satisfaction (JS) for the teaching staff in the United Arab Emirates (UAE). The respondents are chosen from the accredited colleges in the United Arab Emirates (UAE) by convenience sampling method from the cities of Sharjah, Dubai, Abudhabhi and Ajman. They differed in terms of gender, qualifications, tenure of work, department and also the nature of work. A suitable conceptual framework was developed and the proposed model illustrates that flexible work system (FWS) is thought to have an influence on both organizational commitment (OC) and work life balance (WLB). It has been proposed that WLB significantly mediates the relationship between flexible work system and job satisfaction. It is also anticipated that WLB significantly mediates the relationship between organizational commitment (OC) and job satisfaction (JS). A sample size of 224 was chosen and a structured questionnaire was used for collecting the data from the respondents in UAE. The questionnaire consists of 34 statements and they are rated on a likert scale of 1 to 5. For this study, statistical tools like confirmatory factor analysis (CFA) and structural modeling equation (SME) methods have been used through SPSS (version-25) and AMOS (version-25) for assessing the nature of relationships that existed between the studied variables (34 statements in the questionnaire). Prior to testing through structural equation modeling (SEM), the most fundamental criteria tests such as normality and confirmatory factor analysis (CFA) were conducted. As normality was established, the factor loadings were extracted by the procedure of $C F A$. The results from the data analysis indicated that all the hypotheses are supported and it facilitated for the acceptance of the proposed model. Thus, flexible work system (FWS) had direct effect on organizational commitment (OC) and it also had direct effect on work life balance (WLB). Similarly, organizational commitment (OC) is positively related to work-life balance (WLB). Consequently, the work life balance (WLB) displayed positive relationship towards job satisfaction (JS). The results of mediation analysis revealed the indirect effect of flexible work system
\end{abstract}


An Empirical Study of The Relationships between The Flexible Work Systems (FWS), Organizational Commitment (OC), Work Life Balance (WLB) and Job Satisfaction (JS) For The Teaching Staff In The United Arab Emirates (UAE)

(FWS) and organizational commitment (OC) towards job satisfaction (JS) through work-life balance (WLB). The study demonstrates that all the proposed hypotheses are accepted and this is evident from standardized path coefficients.

Keywords: Flexible Work System ((FWS), Organizational Commitment (OC), Work Life Balance (WLB) and Job Satisfaction (JS)

Cite this Article: Vijay Kumar Gudep, An Empirical Study of The Relationships between The Flexible Work Systems (FWS), Organizational Commitment (OC), Work Life Balance (WLB) and Job Satisfaction (JS) For The Teaching Staff In The United Arab Emirates (UAE), International Journal of Management, 10 (5), 2019, pp. 11-27. http://iaeme.com/Home/issue/IJM?Volume=10\&Issue $=5$

\section{INTRODUCTION}

The dynamically evolving modern technological advancements, changes in the global economy, and diverse workforce composition call for higher flexibility in work arrangements. There is an increasing body of research evidence which has highlighted about the role played by flexible work systems (FWS) in improving both the behavioral and psychological outcomes like retention and organizational performance (Stavrou et al, 2015). The implications of these FWS are not uniform across the nations and tend to impact upon the organizational commitment of employees as well. Research studies have demonstrated that organizational commitment plays an important role in assessing whether an employee will continue his services in a given organization for the future period of time and work for achieving the goals of that organization. Globally several research studies have been conducted about the relationship between the organizational commitment and other HR variables. Several constructs were created to study the work-family balance phenomena, which has been historically beleaguered by unclear definitions in the academic literature (Wayne et al, 2017; Greenhaus and Allen, 2011). Human Resources Management experts consider the employee work life balance (WLB) as an important factor in fostering employee commitment and job satisfaction. The research study conducted by Laurel et al. (2010), made an attempt to assess the possible relationships that could exist between flexible work arrangement, job satisfaction and turnover intentions. In addition to this, the relationship between flexible work systems, organizational commitment and job satisfaction has emerged as one of the main focuses of studies in the contemporary Human Resource Management (HRM) research. Research study conducted Wayne et al. (2006), examined the relationship between work-family enrichment, job satisfaction and turnover intentions and it highlighted that work-to-family enrichment has a strong impact on the work-on job satisfaction and turnover intentions.

\subsection{Flexible Work Systems (FWS)}

Research studies reveal that a growing number of private companies and public organizations are endeavoring to adopt flexible work arrangements with the intention of supporting their employees to balance their work-family demands. Employers all over the world have adopted flexible work arrangements for attracting and retaining talented employees.

Several research studies have addressed the impact of flexible work practices on the organizational commitment. Employees are likely to utilize flexible work arrangements positively and respond favorably in some select national cultures than all others in general (Masuda et al., 2012; Stavrou et al., 2015).

The role of supervisory support and supervisors' active roles in implementing organizational policies is highlighted in the research study conducted by Koivisto \& Rice, (2016) in the Finland telecommunications industry context. In another similar study, Onken et al., (2018), applied the conservation of resources theory and concluded that flexible work 
schedules and sabbaticals (but not telecommuting) have the potential to increase organizational commitment and decrease turnover intention. This research study addressed how the three flexible work practices (FWPs), flexible work schedules, telecommuting and sabbaticals, impact upon the organizational attractiveness for job seekers and employees. The research findings demonstrated that these effects are partially mediated by perceived autonomy and have implications for practice and future research. The findings suggested that FWPs also increase organizational attachment through increased perceived autonomy.

Relationship between telework practices and organizational commitment has been identified and the potential of telework practices in reducing the turnover intentions has been established (Choi, 2018). This study revealed that non-teleworkers are significantly different and reported the highest level of turnover intention than that of teleworkers. Flexible work arrangements are proved to be attractive from both employee and employer perspectives and provided a range of benefits to both these parties in terms of economic, environmental, social, psychological, and health dimensions (Ciarniene, \& Vienazindiene,2018). This research study was conducted in the context of Lithuania and the respondents included employees from both public and private sector representing different age and sex groups.

Research studies have revealed that these interventions have the potential to create benefit for both organization and employees and thereby increasing the competitiveness (Stavrou and Anderson, 2015). Several gaps were identified with regard to the role of societal values for global firms and one of these identified gaps deals with the limited range of national cultural values in relation to FWAs. Thompson and Taylor (2015) reported three different combinations of temporal and place flexibility are important and they include a) flex-time without flex place, b) flex place without flex-time and c) flex place with flex-time. This study revealed that flextime arrangement without place flexibility allows the employees to alter temporal, but not physical boundaries around work. It was observed that when employees have discretion in choosing where they work but not when they work, and in addition, they have the option to change the physical, but not temporal boundaries of the work systems.

Work time schedules are an important component of work life balance (WLB) and in this context enabling the part time work have been identified by Kossek et al, (2014), as a significant method of facilitating flexible work schedule/arrangement worldwide. Another study conducted by Veen et al, (2016) revealed that that part-time work arrangement is more suitable and acceptable to both career women and wage-earning mothers as they create lower levels of work family interference than the full-time employed persons did. This finding proved that part time working schedule provides a more sufficient WLB for employees and offers advantage of balancing their work life conflict. According to Subramaniam et al., (2010) married working mothers tend to prefer part time work more favorably in anticipation of balancing their personal and work life. The degree of the effectiveness of WLB by is positively influenced by the flexibility of work schedule and it has a tremendous role in circumventing role load for both men and women (Tipping, 2012).

The implementation of flexible working hour concept has emerged as an important method of increasing the sense of responsibility and creating work life balance amongst the employees in modern organizations (Hofacker and Konigs, 2013). There is no universal acceptance on the preferred work schedule during a week, and variations exist globally on the traditional workday schedule which is popularly used as 8 am -5 pm from Monday through Friday. In this context, two of the most widely studied FWAs in the United States and Europe is flextime and flex place (Shockley and Allen, 2007). 
An Empirical Study of The Relationships between The Flexible Work Systems (FWS), Organizational Commitment (OC), Work Life Balance (WLB) and Job Satisfaction (JS) For The Teaching Staff In

The United Arab Emirates (UAE)

\subsection{Organizational Commitment}

Employees' perceptions of work-commitment-oriented practices are increasingly important in developing positive attitudes and behaviors about the environment of which they are a part (Chordiya, 2017). In the currently challenging workplace environment, various researchers, scholars and practitioners have highlighted about the importance of effective HRM practices that foster employee performance and suggested that organizational success is possible with the promotion of commitment oriented HRM policies (Haque et al., (2019); Suprihanto, (2018); Jiang et al., 2017). In line with these studies, Kaur \& Randhawa, (2017) have identified the major dimensions of organizational climate and concluded that the organizational climate exerts a significant amount of influence on both individual and organizational level outcomes. The important dimensions that are identified in this study include supervisory support, pressure to produce, performance feedback, and innovation and flexibility.

In an increasingly challenging and complex workplace, scholars and practitioners have recognized the importance of effective human resource management for individual performance and organizational success. Globally, several studies have been conducted on assessing the employees' perceptions of work-commitment-oriented practices. The moderating effect of organizational commitment on the possible relationships that could exist between work alienation and formalization from a variety of companies of service sector in Istanbul, Turkey is a case in point (Erkmen and Bozkurt, (2016). This research study found that organization's level of formalization affected the employee commitment significantly but the commitment also affected work alienation. However, organizational commitment was not found to be a moderating variable with regard to the relationship between formalization and work alienation. Another research study conducted by Khera, (2017) studied the relationship between organizational commitment and burnout in the Indian retail sector context. The results showed that there is a significant inverse relation among the variables with respect to the demographic variables (gender and marital status), and significant difference existed across level of management and educational qualifications in relation to organizational commitment and burnout. Shahidah et al, (2018) investigated the impact of employee empowerment, teamwork and training on organizational commitment among hotel employees in Malaysia. The study revealed that positive relationship exists between employee empowerment, teamwork and training.

Research study conducted by Cesário and Chambel (2017), studied the employee performance by linking to the organizational commitment and work engagement. The study revealed that the greater an employee's engagement, the more likely he or she is likely to deliver excellent on-the-job performance. The study revealed that organizational affective commitment is important in lowering turnover intentions and it improves the employee's desire to remain in an organization. Research study conducted by Acharya and Dasbiswas, (2017) addressed the issues related to the relationship between leadership style and organizational commitment in paramedical personnel in the Indian context. This study established that there is a significant relationship between leadership style and organizational commitment.

Research studies have revealed that the higher levels of organizational commitment are associated with superior business performance, higher profitability, increased productivity and employee retention. Organizational commitment (OC) is explained by the popular three component model (TCM) which highlighted the relevance of affective commitment, continuance commitment and normative commitment. Ogochukwu et al., (2018) conducted a research study to explore the relationship between examined the performance related pay (PRP) and organizational commitment (OC) in the Nigerian insurance industry. The study revealed that performance related pay (PRP) is positively correlated with the organizational commitment $(\mathrm{OC})$ in the Nigerian insurance industry. 


\subsection{Work Life Balance (WLB)}

Work life balance (WLB) refers to the way employees balance their institutional requirements, policies, procedures and actions without impacting upon their family, friends and community participation. Research studies have indicated that on account of technology changes, modern employees are finding it difficult to strike a balance between office challenges and personal life requirements. In this context, it was noted that flexible hours have the potential to impact upon the mental health of organizational members and likely to contribute to the reduction in stress (Lewis and Humbert 2010). Research study conducted by Kreitner and Kinicki (2012), highlighted that mental health of employees is a significant factor to be reckoned with and it has the potential to create a positive effect on job satisfaction of the employees.

Several research studies have been conducted on assessing the work-life balance methods of employees from various organizations and these studies have identified several work related variables and relationships (Greenhaus \& Kossek, (2014); Zacher \& Frese, (2018); Kiburz et $\mathrm{al}, 2017)$. Another factor related to this phenomenon, is the entry of women into the workforce. This has changed the dynamics of both the workplace and home environment. The dual working couples have also created complexities about the understanding of how families with working women meet their work and family responsibilities and this posed new challenges to the modern organizations (Wheatley, 2012).

Fanny (2018) found that long working hours and irregular working hours (in the context of the event management scenario in Hong Kong) have resulted in low work-life quality and high turnover rate. Similar study conducted by Nizam and Kam (2018)( in the context of the event industry of Malaysia) has revealed that the determinants of work-life balance (WLB) are explained by the variables such as working hours, workload, leave policies, work arrangements and reward schemes and they have a significant impact on the WLB of event industry professionals.

Several organizations across the world are supporting their employees to enhance their work-life balance efforts through flexible work systems (Morganson et al. 2014; Munn, (2013). Wilkinson et al., 2018) conducted an exploratory study of the WLB experiences of solo-living, childless young to middle aged managers and professionals through organizational justice theory and emphasized the importance of assessing the fairness of work-life balance policies and flexible working arrangements. His study addressed work-life balance issues for one person living all alone or someone who does not stay with a partner or any of the family members. Similarly, enrichment across the roles may not take place due to the specific intrinsic nature of those roles but yet some amount of balance must be existing thereof. Present studies indicate that conflict and enrichment are important issues in work-family constructs but are distinct from the notion of the balance construct (Syrek et al., 2013).

\subsection{Job Satisfaction (JS)}

Job satisfaction refers to the positive, affective psychological work related state of mind that leads active involvement of employees in their duties. A satisfied employee is described as someone who is persistently and voluntarily involved in work (Gamage and Jayatilake, 2019). Although several research studies were conducted on assessing the relationship between job satisfaction and employee turnover, less research evidence is available on how it affects the employee commitment, creativity at work, and other employee intentions (Lee and Mei,(2014); Jha and Jha,(2019); Xiao and Yi,2019). Research studies have revealed that work intrusions into the personal life of employees have significantly influenced their attitudes towards work and work related behaviors (Chou et al., 2012).

Contemporary research studies described the concept of job satisfaction as an evaluative state that varies over a period time (Ritzenhöfer et al., (2019); Wolter et al., (2019)). Research 
An Empirical Study of The Relationships between The Flexible Work Systems (FWS), Organizational Commitment (OC), Work Life Balance (WLB) and Job Satisfaction (JS) For The Teaching Staff In

The United Arab Emirates (UAE)

study made by Dalkrani and Dimitriadis, (2018), examined the effect of job satisfaction on employee commitment and explained how intrinsic need satisfaction of the employees at work influences their attitudes towards job. Noviantoro, (2018) conducted a landmark research study in the context of Indonesia about the job satisfaction as well as the extent of the effect of work passion on teacher's achievement. This study empirically investigated about the impact of incentives on the teachers' job satisfaction and also the extent of direct effect of job satisfaction on teachers' work achievement. The study concluded that there is a direct but yet a nonsignificant effect association between the variables of work passion on teacher job satisfaction. Kovacs et al., (2018), explored the different forms of job dissatisfaction by linking to the motivation and performance. The authors investigated about the stability of the dissatisfaction forms over a period of time by contenting it to a five-month period with emphasis on assessing their relationship with well-being, motivation and (self-reported) performance. Pomirleanu and Mariadoss (2015), investigated about the influence of organizational and functional support on the job satisfaction of salespersons. Their findings are in line with social exchange theories that lay emphasis on the principles of reciprocation, highlighting the intention of the employees who feel supported by the organization.

Qu and Zao (2012) demonstrated that work interference with family life has a negative impact on the employee behavior and it reduces job satisfaction. Research studies stated that those who work for long and extended work hours, tend to have poor work life balance (WLB) and develop job insecurity (Balven et al., (2018); Wilkinson et al., 2018). The research study conducted by Laurel et al., (2010), revealed that work-to-family enrichment has mediated the relation between flexible work systems (FWS) and both job satisfaction and turnover intentions, despite controlling demographical variables like gender, age, marital status, education and number of children. The differences between the various generational cohorts with regard to job satisfaction were studied by Young et al., (2013) and this study found the attitudinal differences between the baby boomers in comparison to Generation X and Generation $\mathrm{Y}$. The study revealed that the baby boomers were more satisfied with their job involvements in comparison to Generation X and Generation Y (Beutell, 2013; Guberman et al., 2012).

\section{RESEARCH HYPOTHESES AND FRAMEWORK}

The conceptual framework presented in figure-1 below highlights the summary of the variables and hypotheses used in this research study. The proposed model illustrates that flexible work system (FWS) is thought to have an influence on both organizational commitment and work life balance (WLB). It can be seen in the proposed model that work life balance (WLB) influences the employee job satisfaction. The above proposed model consists of four hypotheses that are mentioned below.



Figure 1 Conceptual Model Framework 
Hypothesis 1: Flexible work systems (FWS) have a positive impact on organizational commitment.

Hypothesis 2: Flexible work systems (FWS) have a positive impact on work life balance (WLB).

Hypothesis 3: Organizational commitment has a positive impact on work life balance (WLB).

Hypothesis 4: work life balance (WLB) has a positive impact on Job satisfaction.

Hypothesis 5a: WLB significantly mediates the relationship between flexible work system and job satisfaction.

Hypothesis 5b: WLB significantly mediates the relationship between organizational commitment and job satisfaction.

\section{RESEARCH METHODOLOGY}

For this research study, a structured questionnaire was used for collecting the data from the respondents in UAE. The respondents are chosen on the basis of availability and hailed from teaching profession from Sharjah, Dubai, Abudhabhi and Ajman in the United Arab Emirates (UAE). In this questionnaire, questions related to the gender, educational qualifications, teaching tenure, department background and nature of work are included.

This questionnaire has nine statements on FWS, seven statements on OC, seven statements on WLB and eleven statements on JS. The statements are rooted on a 5 point likert scale and based on the review and analysis of the contemporary literature review. For measuring flexible work systems (FWS), the four items of the study made by McNamara et al., (2012) were used. Leader in-group behavior was measured by using the scale suggested by Platow and van Knippenberg (2001). Respect was measured with three items from the respect scale used by Tyler and Blader (2002).

For assessing the organizational climate three dimensions of Meyer and Allen (1991) scale have been used. The three dimensions are affective commitment, continuance commitment and normative commitment.

For work life balance (WLB), the measures used in the present research were drawn from previously published literature. We measured followers' work-life balance by using the five items from the work-life balance scale of Syrek et al., 2013.

For Job Satisfaction, the job dimensions were selected from the job satisfaction scales used in the study by Janicijevic et al., (2015) and Millana, et al., (2013).

For this study, statistical tools like confirmatory factor analysis (CFA) and structural modeling equation (SME) methods have been used through SPSS (version-25) and AMOS (version-25) for assessing the nature of relationships that existed between the studied variables (34 statements in the questionnaire). These tools were used to assess the relationships between the flexible work systems (FWS), organizational commitment (OC), work life balance (WLB) and job satisfaction (JS) for the teaching staff in the United Arab Emirates (UAE) among the model constructs.

\section{DATA ANALYSIS AND RESULTS}

Data analysis for the current research study was conducted by SPPS and AMOS (22.0 version). Prior to the testing of the path relationships, the preliminary tests were carried to confirm the reliability and validity of the scales that were used for this study. The demographic profile of the respondents is presented in the Table 1. 
An Empirical Study of The Relationships between The Flexible Work Systems (FWS), Organizational Commitment (OC), Work Life Balance (WLB) and Job Satisfaction (JS) For The Teaching Staff In

The United Arab Emirates (UAE)

Convenience sampling method was chosen for the data collection. The limited number of respondents justified using this method. The survey was conducted during July 2018 to August 2019. These questionnaires were administered to a total of 250 respondents and from this only 224 questionnaires were in the correct format. Therefore, the effective sample size is 224 . The respondents are teaching staff members and chosen from the accredited colleges in the United Arab Emirates (UAE) by convenience sampling method. They differed in terms of gender, qualifications, tenure of work, department and also the nature of work. The female respondents constituted 50.4\% and respondents with $\mathrm{PhD}$ qualification are $61.2 \%$. For the tenure of work respondents with above the 3-5 years constituted $42.4 \%$ and the Business Department teachers are around $32.6 \%$. The full time faculty staffs constitute $57.6 \%$ and the rest is part-time staff.

Table 1 Demographical analysis of the respondents

\begin{tabular}{|c|l|c|c|}
\hline Demographics & \multicolumn{1}{|c|}{ Category } & Frequency & Percentage \\
\hline \multirow{3}{*}{ Gender } & Male & 111 & 49.6 \\
\cline { 2 - 4 } & Female & 113 & 50.4 \\
\hline \multirow{3}{*}{ Qualification } & Ph.D & 137 & 61.2 \\
\cline { 2 - 4 } & PG & 87 & 38.8 \\
\hline \multirow{5}{*}{ Department } & 1 year & 43 & 19.2 \\
\cline { 2 - 4 } & 2 year & 71 & 31.7 \\
\cline { 2 - 4 } & 3-5 year & 95 & 42.4 \\
\cline { 2 - 4 } & Above 6 year & 15 & 6.7 \\
\cline { 2 - 4 } & Business \& Accounting & 73 & 32.6 \\
\cline { 2 - 4 } & Information Systems/Computing/IT & 43 & 19.2 \\
\cline { 2 - 4 } & English & 25 & 11.2 \\
\cline { 2 - 4 } & Arabic & 54 & 24.2 \\
\cline { 2 - 4 } & General Education & 29 & 12.9 \\
\hline \multirow{5}{*}{ Nature of work } & Full Time & 129 & 57.6 \\
\cline { 2 - 4 } & Part Time & 95 & 42.4 \\
\hline
\end{tabular}

The following Table 2 shows the findings of descriptive statistics; square root of AVE and inter-correlation among the study variable. As expected and in with the literature review cited in this research paper, the results showed a positive correlation among all the study variables viz., flexible work system $(\mathrm{r}=0.48, \mathrm{p}<0.000)$; organizational commitment $(\mathrm{r}=0.27, \mathrm{p}<0.000)$; work-life balance $(\mathrm{r}=0.57, \mathrm{p}<0.05)$ towards job satisfaction. In this research study, all the research study variables have inter-construct correlation. This further indicates the preliminary acceptance to proceed for the testing of hypothesized relationships that are proposed for this study.

Table 2 Descriptive, Inter correlation and Square root of AVE

\begin{tabular}{|c|l|c|c|c|c|c|c|}
\hline Number & \multicolumn{1}{|c|}{ Constructs } & Mean & SD & $\mathbf{1}$ & $\mathbf{2}$ & $\mathbf{3}$ & $\mathbf{4}$ \\
\hline 1 & Flexible work system & 2.93 & 0.64 & 0.78 & & & \\
\hline 2 & Organizational commitment & 2.36 & 0.68 & $0.52^{* *}$ & 0.80 & & \\
\hline 3 & Work-life balance & 4.00 & 0.63 & $0.35^{* *}$ & $0.30^{* *}$ & 0.90 & \\
\hline 4 & Job satisfaction & 3.71 & 0.59 & $0.48^{* *}$ & $0.27^{* *}$ & $0.57^{* *}$ & 0.84 \\
\hline
\end{tabular}

Notes: Diagonal line placed in italic style show the square root of the AVE of each construct. **Significant at 0.01 level (two-tailed) 
Further it is required to examine the reliability and validity of the instrument to proceed with structural equation modeling (SEM). Thus prior to test structural equation modeling (SEM), the most fundamental criteria such as normality and confirmatory factor analysis (CFA) was conducted. As normality was established, the factor loadings were extracted by the procedure of CFA.

The result of KMO value $(0.946, \mathrm{p}<0.000)$ demonstrates the adequacy of sample chosen. All the item loadings are found to be higher than 0.60, which meets the threshold values as given by Hair et al., (2012). Thus the validity of the instrument is established. Subsequently, the reliability is assessed by estimating the value of Cronbach's alpha, Composite Reliability (CR), and Average Variance Extracted (AVE). These values also meet the above mentioned requirements appropriately $(\alpha>0.8, \mathrm{CR}>0.7$ and $\mathrm{AVE}>0.8)$. The results of established validity and reliability were exhibit in Table 2 .

Table 2 Factor loadings, Reliability and Validity

\begin{tabular}{|c|c|c|c|c|}
\hline Items & $\begin{array}{c}\text { Cronbach's } \\
\text { Alpha }\end{array}$ & $\begin{array}{c}\text { Factor } \\
\text { Loadings }\end{array}$ & CCR & AVE \\
\hline \multicolumn{5}{|l|}{ Flexible Work Systems } \\
\hline $\begin{array}{l}\text { FW1: My supervisor seeks my opinions while planning } \\
\text { my classroom schedules. }\end{array}$ & \multirow[t]{9}{*}{0.876} & .636 & \multirow[t]{9}{*}{0.874} & \multirow[t]{9}{*}{0.691} \\
\hline $\begin{array}{l}\text { FW2: My supervisor discusses about the course } \\
\text { allocations in advance. }\end{array}$ & & .715 & & \\
\hline $\begin{array}{l}\text { FW3: I am allowed to reschedule my teaching tasks, } \\
\text { meetings and other academic involvements. }\end{array}$ & & .564 & & \\
\hline $\begin{array}{l}\text { FW4: My peer group supports me in case of } \\
\text { emergencies. }\end{array}$ & & .595 & & \\
\hline $\begin{array}{l}\text { FW5: Work requirements are not rigid and flexibility is } \\
\text { displayed to accommodate instructor requests. }\end{array}$ & & .712 & & \\
\hline $\begin{array}{l}\text { FW6: My institution encourages the academic staff to } \\
\text { use technology for office communications. }\end{array}$ & & .783 & & \\
\hline $\begin{array}{l}\text { FW7: Our institution encourages the staff members to } \\
\text { identify a peer support resource to share job } \\
\text { responsibilities in case of emergencies. }\end{array}$ & & .568 & & \\
\hline $\begin{array}{l}\text { FW8: Requests for flexible work arrangements are } \\
\text { handled equitably without any bias. }\end{array}$ & & .586 & & \\
\hline $\begin{array}{l}\text { F9: My supervisor expresses willingness on discussions } \\
\text { about the work flexibility issues. }\end{array}$ & & .549 & & \\
\hline \multicolumn{5}{|l|}{ Organizational commitment } \\
\hline $\begin{array}{l}\text { OC1: This institution provides an opportunity for } \\
\text { offering suggestions on framing the departmental } \\
\text { objectives. }\end{array}$ & \multirow[t]{6}{*}{0.868} & .689 & \multirow[t]{6}{*}{0.871} & \multirow[t]{6}{*}{0.656} \\
\hline $\begin{array}{l}\text { OC2: I am emotionally attached to this institution and } \\
\text { have no intentions to switchover to another organization } \\
\text { at the moment. }\end{array}$ & & .671 & & \\
\hline $\begin{array}{l}\text { OC3: I am committed to this institution on account of } \\
\text { the competitive pay package. }\end{array}$ & & .710 & & \\
\hline $\begin{array}{l}\text { OC4: I recommend this institution to my friends and all } \\
\text { other prospective aspirants. }\end{array}$ & & .703 & & \\
\hline $\begin{array}{l}\text { OC5: My continuance with this organization is based on } \\
\text { my current necessities only. }\end{array}$ & & .747 & & \\
\hline $\begin{array}{l}\text { OC6: This institution provides equal opportunities for } \\
\text { career development. }\end{array}$ & & .713 & & \\
\hline
\end{tabular}


An Empirical Study of The Relationships between The Flexible Work Systems (FWS), Organizational

Commitment (OC), Work Life Balance (WLB) and Job Satisfaction (JS) For The Teaching Staff In

The United Arab Emirates (UAE)

\begin{tabular}{|c|c|c|c|c|}
\hline $\begin{array}{l}\text { OC7: My peer group is committed to this institution and } \\
\text { encourages me on organizational commitment. }\end{array}$ & & .685 & & \\
\hline \multicolumn{5}{|l|}{ Work Life Balance (WLB) } \\
\hline $\begin{array}{l}\text { WLB1: Working in this institution has an impact on my } \\
\text { family life. }\end{array}$ & \multirow[t]{7}{*}{0.949} & .792 & \multirow[t]{7}{*}{0.945} & \multirow[t]{7}{*}{0.812} \\
\hline $\begin{array}{l}\text { WLB2: Work pressure and other role requirements } \\
\text { sometimes emerge as source of stress. }\end{array}$ & & .805 & & \\
\hline $\begin{array}{l}\text { WLB3: I sometimes think about the work requirements } \\
\text { while I am at home. }\end{array}$ & & .789 & & \\
\hline $\begin{array}{l}\text { WLB4: I am able to balance both work and family } \\
\text { requirements in a successful manner. }\end{array}$ & & .809 & & \\
\hline $\begin{array}{l}\text { WLB5: I get opportunities to spend quality time with } \\
\text { my friends and family on weekends. }\end{array}$ & & .778 & & \\
\hline $\begin{array}{l}\text { WLB6: I sometimes feel that my family related issues } \\
\text { distract me from focusing on the office work. }\end{array}$ & & .706 & & \\
\hline $\begin{array}{l}\text { WLB7: My family members understand my work } \\
\text { pressure and offer support while I work on my office } \\
\text { work from home. }\end{array}$ & & .591 & & \\
\hline \multicolumn{5}{|l|}{ Job Satisfaction } \\
\hline $\begin{array}{l}\text { JS 1: This institution encourages staff to offer } \\
\text { innovative ideas for improving the quality of work life. }\end{array}$ & 0.913 & .599 & 0.906 & 0.717 \\
\hline $\begin{array}{l}\text { JS 2: Working in this institution has sharpened my } \\
\text { academic skills. }\end{array}$ & & .746 & & \\
\hline $\begin{array}{l}\text { JS 3: My supervisor tends to be positive and appreciates } \\
\text { my positive contributions. }\end{array}$ & & .684 & & \\
\hline $\begin{array}{l}\text { JS 4: This institution offers appreciation letters to the } \\
\text { staff on significant contributions. }\end{array}$ & & .733 & & \\
\hline $\begin{array}{l}\text { JS 5: I am satisfied with the variety of experiences that } \\
\text { emerge out of my work involvements. }\end{array}$ & & .746 & & \\
\hline $\begin{array}{l}\text { JS6: My supervisor provides an unbiased feedback } \\
\text { about my performance on a regular basis. }\end{array}$ & & .707 & & \\
\hline $\begin{array}{l}\text { JS7: My work group is collaborative and encourages } \\
\text { lively discussions on the academic issues. }\end{array}$ & & .738 & & \\
\hline $\begin{array}{l}\text { JS 8: This institution allows discussions on work } \\
\text { overload }\end{array}$ & & .575 & & \\
\hline $\begin{array}{l}\text { JS 9: Extra workload allocations are backed by both } \\
\text { supervisor and peer group support. }\end{array}$ & & .646 & & \\
\hline $\begin{array}{l}\text { JS 10: My institution offers good financial and non- } \\
\text { financial incentives in comparison to others in the } \\
\text { market. }\end{array}$ & & .580 & & \\
\hline $\begin{array}{l}\text { JS 11: I feel that my performance is improved } \\
\text { considerably, after joining this Institution. }\end{array}$ & & .749 & & \\
\hline
\end{tabular}

\subsection{Measurement model}

Prior to test the hypothesized relationship of the proposed model, the model's goodness of fit is examined. For establishing the model fit, the proposed measurement model is validated by confirmatory analysis using AMOS. The findings emphasized the goodness of fit for the proposed model. As suggested by Hair et al. (2019), the model established the acceptance of fit by following indices estimates: $\chi 2(\mathrm{CMIN} / \mathrm{df})=0.988$, $\mathrm{p}$-value $=0.002, \mathrm{GFI}=0.924, \mathrm{AGFI}=$ $0.869, \mathrm{CFI}=0.941, \mathrm{NFI}=0.893, \mathrm{IFI}=0.943, \mathrm{TLI}=0.898, \mathrm{RMSEA}=0.070$. 


\subsection{Structural Model}

To test the proposed hypotheses, the standardized path co-efficient values are estimated in the structural equation modeling (Figure 2-Revised estimates of the model). The relationships of the variables, Flexible Work Systems (FWS), Organizational Commitment (OC), Work Life Balance (WLB) and Job Satisfaction (JS) were examined. The results from the Table 4 indicated that all the hypotheses results are fully supported and it facilitated the acceptance of the proposed model.

Flexible Work Systems (FWS), showed significant positive relationship with organizational commitment $(\beta=0.268, p<0.000)$ and also positively related to work-family balance $(\beta=0.398$, $\mathrm{p}<0.000$ ). Thus, flexible work system had direct effect on organizational commitment (as a result, H1 is accepted) and also had direct effect on work life balance (as a result, H2 is accepted) as well. Similarly, organizational commitment positively related to work-life balance $(\beta=0.193, p<0.000)$ and thus confirms the direct effect (H3 is also accepted). Consequently, the work life balance showed positive relationship towards job satisfaction $(\beta=0.624, p<0.000)$. Thus, WLB had direct effect on JS (H4 accepted).

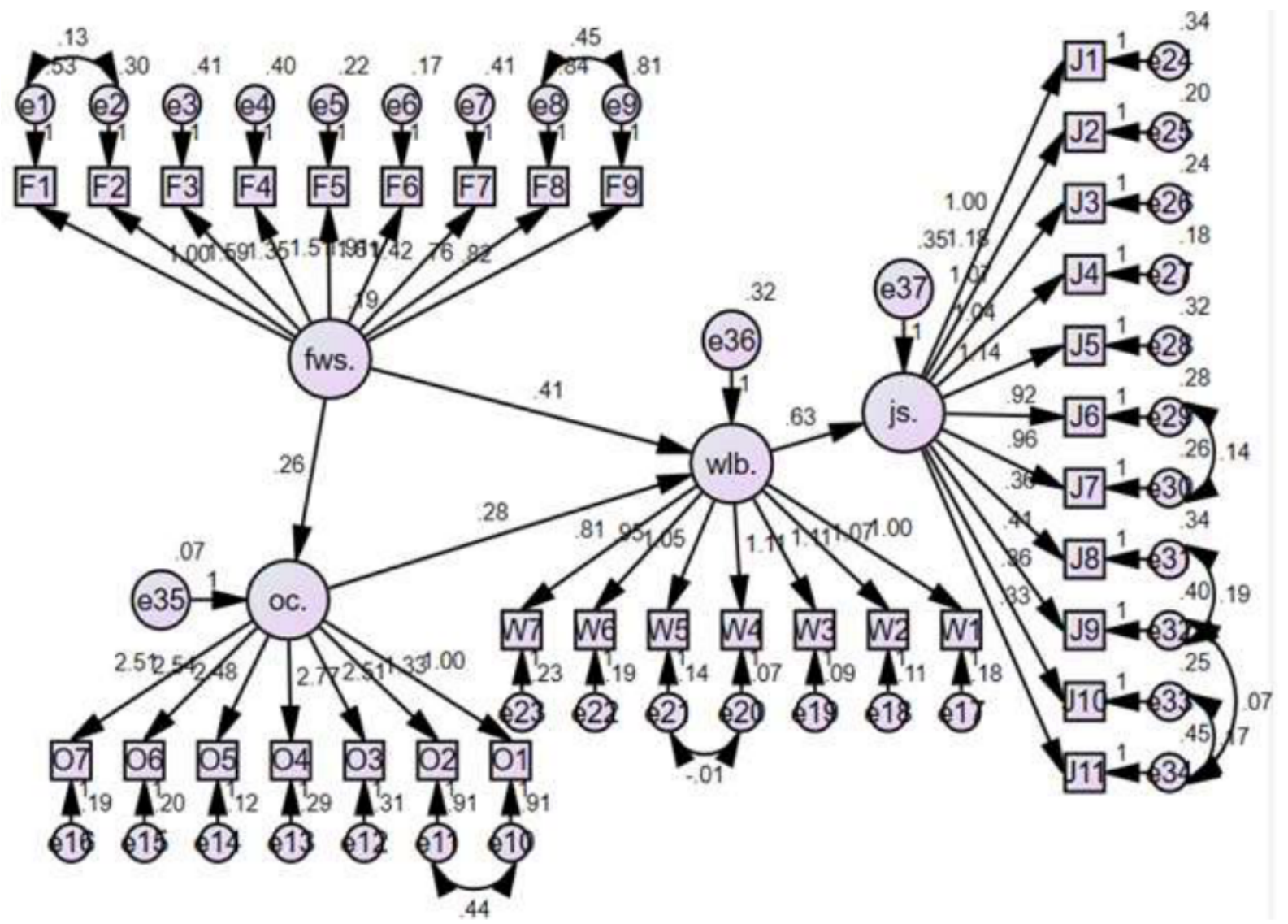

Figure 2 Revised estimates of the model

Table 4 Hypothesis Testing Results

\begin{tabular}{|c|c|c|c|c|c|}
\hline Hypothesis & Relationship & $\begin{array}{c}\text { Standard } \\
\text { Estimates }\end{array}$ & CR (t-value) & p-value & Decision \\
\hline H1 & FWS $\rightarrow$ OC & 0.078 & 3.444 & 0.000 & Accepted \\
\hline H2 & FWS $\rightarrow$ WLB & 0.106 & 3.755 & 0.000 & Accepted \\
\hline H3 & OC $\rightarrow$ WLB & 0.096 & 2.019 & 0.000 & Accepted \\
\hline H4 & WLB $\rightarrow$ JS & 0.082 & 7.614 & 0.000 & Accepted \\
\hline
\end{tabular}


An Empirical Study of The Relationships between The Flexible Work Systems (FWS), Organizational Commitment (OC), Work Life Balance (WLB) and Job Satisfaction (JS) For The Teaching Staff In

The United Arab Emirates (UAE)

Notes: FWS, flexible work system; WLB, work-life balance; OC, organizational commitment; JS, job satisfaction; ${ }^{* *} \mathrm{p}<0.01$

For testing H5, the mediation effect of work-life balance, the indirect effects were estimated by bootstrapping approach of Hayes and Preacher (2010). The Table-5 indicates the results of mediation analysis. The indirect effect of flexible work system and organizational commitment towards job satisfaction through work-life balance was significant which supports the acceptance of hypothesis H5a and H5b. Finally, it can be seen that all the proposed hypotheses are accepted and it is evident from standardized path coefficients.

Table 5 Mediation Analysis

\begin{tabular}{|c|c|c|c|c|c|c|}
\hline $\begin{array}{c}\text { Relationship } \\
(\text { Bootstrapping) }\end{array}$ & Indirect & SE & $\begin{array}{c}\text { Lower CI } \\
\mathbf{( 9 5 \% )}\end{array}$ & $\begin{array}{c}\text { Upper CI } \\
\mathbf{( 9 5 \% )}\end{array}$ & p-value & Decision \\
\hline FWS $\rightarrow$ WLB $\rightarrow$ JS & 0.150 & 0.031 & 0.096 & 0.217 & 0.000 & Accepted \\
\hline OC $\rightarrow$ WLB $\rightarrow$ JS & 0.141 & 0.032 & 0.082 & 0.029 & 0.000 & Accepted \\
\hline
\end{tabular}

Notes: FWS, flexible work system; WLB, work-life balance; OC, organizational commitment; JS, job satisfaction; $* * p<0.01$

\section{CONCLUSIONS}

The research findings established that flexible work systems (FWS) and organizational commitment (OC) are significant factors in fostering and facilitating a viable work life balance (WLB) for the teaching staff members in UAE. The results of the data analysis established that work life balance (WLB) is mediating the impact on job satisfaction (JS). The indirect effect of flexible work systems (FWS) and organizational commitment (OC) on job satisfaction (JS) through work life balance (WLB) is evident. These findings are in line with the research study conducted by Gudep et al., (2012) and other research studies alike. For work life balance (WLB), the results are consistent with the findings of the research studies of Augoustaki and Frankfort, (2019) and Wilkinson et al., (2018). Therefore, based on the analysis of the data of this research study, it can be inferred that flexible work systems (FWS) and organizational commitment (OC) have the potential to create Job Satisfaction (JS) amongst the teaching staff members in UAE through the mediation of work life balance (WLB).

\section{SCOPE FOR FUTURE STUDY}

The current research study is limited to a few select emirates in UAE and its scope can be further increased by incorporating a large sample size form all the other emirates as well. More variables can be identified by analyzing the recent research studies in this area. Work overload can also be considered as an influencing factor while reckoning with work life balance (WLB). Comparative research studies can also be planned within the Middle East countries by not limiting to UAE alone. Since this research study has established that flexible work systems (FWS) and organizational commitment (OC) are significant factors in fostering and facilitating work life balance (WLB), the antecedents of job satisfaction (JS) may also be researched in detail by not restricting to these construct variables.

\section{REFERENCES}

[1] Acharya, R., \& Dasbiswas, A. K, A Study on the Relationship between Organizational Commitment and Leadership Style on Paramedical Personnel in Kolkata. International Journal of Business Insights \& Transformation, 11(1), 2017, pp 80-84. 
[2] Avgoustaki, A, \& Frankort, H. T. W, Implications of Work Effort and Discretion for Employee Well-Being and Career-Related Outcomes: An Integrative Assessment. ILR Review, 72(3), 2019, pp 636-661.

[3] Balven, R., Fenters, V., Siegel, D. S., \& Waldman, D, Academic Entrepreneurship: The Roles of Identity, Motivation, Championing, Education, Work-Life Balance, and Organizational Justice. Academy of Management Perspectives, 32(1), 2018, pp 21-42.

[4] Beutell, N.J, Generational Differences in Work-Family Conflict and Synergy, International Journal of Environmental Research and Public Health, Vol.10 (6), 2013, pp. 2544-2559.

[5] Cesário, F., \& Chambel, M. J, Linking Organizational Commitment and Work Engagement to Employee Performance. Knowledge \& Process Management, 24(2), 2017, pp 152-158.

[6] Chou, H.Y., Hecker, R. and Martin, A, 'Predicting nurses_wellbeing from job demands and resources: a cross-sectional study of emotional labor', Journal of Nursing Management, Vol. 20(4), 2012, pp. 502-511.

[7] Chordiya, R.,Sabharwal,M \& Goodman,D, Affective Organizational Commitment and Job Satisfaction: A Cross-National Comparative Study. Public Administration, 95(1), 2017, pp 178-195.

[8] Choi, S, Managing Flexible Work Arrangements in Government: Testing the Effects of Institutional and Managerial Support. Public Personnel Management, 47(1), 2018, pp 2650.

[9] Ciarniene, R., \& Vienazindiene, M, Flexible Work Arrangements from Generation and Gender Perspectives: Evidence from Lithuania. Engineering Economics, 29(1), 2018, pp 84-92.

[10] Dalkrani, M., \& Dimitriadis, E, the Effect of Job Satisfaction on Employee Commitment. International Journal of Business \& Economic Sciences Applied Research, 11(3), 2018, pp 16-23.

[11] Erkmen, T., \& Bozkurt, S, Moderating Effect of Organizational Commitment on the Relationship between Work Alienation and Formalization. Journal of Economic Development, Management, IT, Finance \& Marketing, 8(2), 2016, pp 16-23.

[12] Fanny Yuk Fun Young, Work-Life Balance and Mental Health Conditions During a Reduction in the Number of Working Hours: A Follow-up Study of Hong Kong Retail Industry Workers. International Journal of Business \& Information, 13(4), 2018, pp 489504.

[13] Gamage, S. K., \& Jayatilake, L. V. K, Impact of Employee Engagement on Job Satisfaction of Employees in Insurance Industry of Sri Lanka. Annual International Conference on Accounting \& Finance, 2019, 39-44.

[14] Guberman, N., Lavoie, J.P., Blein, L. and Olazabal, I, Baby Boom Caregivers: Care in the Age of Individualization, The Gerontologist, Vol. 52(2), 2012, pp.210-218.

[15] Greenhaus, J. H., \& Kossek, E. E, The contemporary career: A work-home perspective. Annual Review of Organizational Psychology and Organizational Behavior, 1:2014, pp 361-388.

[16] Greenhaus, J. H., \& Allen, T. D. 2011. Work-family balance: A review and extension of the literature. In J. C. Quick \& L. E. Tetrick (Eds.), Handbook of occupational health psychology (2nd ed.): Washington, DC: American Psychological Association, 2012, pp $165-183$.

[17] Gudep,Vijaya.K, Abbas, Ali \& Kanaka, Durga, The Effect of Job Satisfaction On Creativity: An Empirical Study of Employees' Job Satisfaction from Select Service Industries in Oman and UAE, Omani Journal of Applied Sciences, Volume 4, Issue 1, July 2012.

[18] Haque, A., Fernando, M., \& Caputi, P, the Relationship between Responsible Leadership and Organisational Commitment and the Mediating Effect of Employee Turnover 
An Empirical Study of The Relationships between The Flexible Work Systems (FWS), Organizational Commitment (OC), Work Life Balance (WLB) and Job Satisfaction (JS) For The Teaching Staff In

The United Arab Emirates (UAE)

Intentions: An Empirical Study with Australian Employees. Journal of Business Ethics, 156(3), 2019, pp 759-774.

[19] Hayes, A. F., \& Preacher, K. J, Quantifying and Testing Indirect Effects in Simple Mediation Models When the Constituent Paths Are Nonlinear. Multivariate Behavioral Research, 45(4), 2010, pp 627-660.

[20] Hair, J. F., Ringle, C. M., Gudergan, S. P., Fischer, A., Nitzl, C., \& Menictas, C, Partial least squares structural equation modeling-based discrete choice modeling: an illustration in modeling retailer choice. Business Research, 12(1), 2019, pp 115-142.

[21] Hair, J., Sarstedt, M., Ringle, C., \& Mena, J, An assessment of the use of partial least squares structural equation modeling in marketing research. Journal of the Academy of Marketing Science, 40(3), 2012, pp 414-433.

[22] Hofacker D, Konig, S, Flexibility and work-life conflict in times of crisis: a gender perspective. International Journal of Sociology and Social Policy 33 (9-10), 2013, pp 613635.

[23] Janicijevic, N., \& Paunovic, K. I, Employee and the Self-Employed Job Satisfaction: Similarities and Differences. Management: Journal of Sustainable Business \& Management Solutions in Emerging Economies, 24(1), 2019, pp 43-51.

[24] Jiang, Z., Gollan, P. J., \& Brooks, G, Relationships between organizational justice, organizational trust and organizational commitment: a cross-cultural study of China, South Korea and Australia. International Journal of Human Resource Management, 28(7), 2017, pp 973-1004.

[25] Jha, Y., \& Jha, S, Examining the Relationship between Job-Family Interference and Job Satisfaction: The Role of Organizational, Task, and Personal Resources as Moderators. Journal of Management Research (09725814), 19(3), 2019, pp 180-192.

[26] Kaur, K., \& Randhawa, G, Organizational Climate \& Commitment: An Analysis of Food Processing Industry of Punjab. Indian Journal of Industrial Relations, 53(2), 2017, pp 265276.

[27] Khera, A, Impact of Organizational Commitment on Burnout: A Study among the Employees in Retail Sector in India. CLEAR International Journal of Research in Commerce \& Management, 8(7), 2017, pp 58-62.

[28] Kiburz, K. M., Allen, T. D., \& French, K. A, Work-family conflict and mindfulness: Investigating the effectiveness of a brief training intervention. Journal of Organizational Behavior, 38: 2017, pp 1016-1037.

[29] Kovacs, C., Stiglbauer, B., Batinic, B., \& Gnambs, T, Exploring Different Forms of Job (Dis) Satisfaction and Their Relationship with Well- Being, Motivation and Performance. Applied Psychology: An International Review, 67(3), 2018, pp 523-556.

[30] Kreitner R, Kinicki A, Organizational behavioral (10th ed). Boston: McGraw-Hill, 2012

[31] Kossek, E. E., Hammer, L. B., Thompson, R. J., \& Burke, L. B., Leveraging workplace flexibility: Fostering engagement and productivity. SHRM foundation's effective practice guidelines series. Alexandra, VA: SHRM Foundation, 2014

[32] Kossek, E. E., \& Lautsch, B. A. (2012). Work-family boundary management styles in organizations A cross-level model. Organizational Psychology Review, 2, 2012, pp 152171.

[33] Koivisto, S., \& Rice, R. E, Leader proto-typicality moderates the relation between access to flexible work options and employee feelings of respect and leader endorsement. International Journal of Human Resource Management, 27(22), 2016, pp 2771-2789.

[34] Laurel, A. McNall., Aline, D. Masuda, \&Jessica, M.Nicklin, Flexible work arrangements, job satisfaction, and turnover intentions: The mediating role of work-to-family enrichment. The Journal of Psychology, 2010, 144(1), 61-81. 
[35] Lee, Hung-Wen, and Mei-Chun Lin.,A Study of Salary Satisfaction and Job Enthusiasm Mediating Effects of Psychological Contract. Applied Financial Economics 24 (24): 2014, pp 1577-83.

[36] Lewis S, Humbert AL, Work-life balance, flexible working policies and the gendered organization. Equality, diversity and inclusion. International Journal 29 (3), 2010, pp 239254.

[37] Masuda, A. D., Poelmans, S. A., Allen, T. D., Spector, P. E., Lapierre, L. M., Cooper, C. L., \& Lu, L, Flexible work arrangements availability and their relationship with work- tofamily conflict, job satisfaction, and turnover intentions: A comparison of three country clusters. Applied Psychology, 61(1), 2012, pp 1-29.

[38] McNamara, T. K., Pitt-Catsouphes, M., Brown, M., \& Matz-Costa, C, Access to and utilization of flexible work options. Industrial Relations, 51, 2012, pp 936-965.

[39] Meyer, J. P., \& Allen, N. J, Commitment to organizations and occupations: Extension and test of a three-component conceptualization. Journal of Applied Psychology, 78(4), 1991, pp 538-551

[40] Milana, E, Impact of Job Satisfaction on Public Service Quality: Evidence from Syria. Serbian Journal of Management, 13(2), 2018, pp 233-250.

[41] Morganson, V. J., Litano, M. L., \& O’Neill, S. K, Promoting work-family balance through positive psychology: A practical review of the literature. The Psychologist-Manager Journal, 17(4), 2014, pp 221-244.

[42] Munn, S. L, Unveiling the work-life system: The influence of work-life balance on meaningful work. Advances in Developing Human Resources, 15(4), 2013, pp 401-417.

[43] Nizam, I., \& Kam, C, The Determinants of Work-Life Balance in the Event Industry of Malaysia. International Journal of Management, Accounting \& Economics, 5(3), 2018, pp 141-168.

[44] Noviantoro, D, The Effect of Incentives, Work Passion and Job Satisfaction on Vocational Secondary School (SMK) Teacher Work Achievement In The City Of Medan, Indonesia. International Journal of Business \& Economic Sciences Applied Research, 11(3), 2018, pp $7-15$.

[45] Ogochukwu Augustine Isimoya, Olubayo Thomas Olajide \& Akinwunmi Kunle Onafalujo. , Performance Related Pay and Organizational Commitment - evidence from Nigeria. Journal of Economics and Management, Vol. 34 (4), 2018

[46] Onken-Menke, G., Nüesch, S., \& Kröll, C, Are you attracted? Do you remain? Metaanalytic evidence on flexible work practices. Business Research, 11(2), 2018, pp 239-277.

[47] Platow, M. J., \& van Knippenberg, D, A social identity analysis of leadership endorsement: The effects of leader in-group prototypicality and distributive intergroup fairness. Personality and Social Psychology Bulletin, 27, 2001, pp 1508-1519.

[48] Pomirleanu, N., \& John Mariadoss, B, The influence of organizational and functional support on the development of salesperson job satisfaction. Journal of Personal Selling \& Sales Management, 35(1), 2015, pp 33-50.

[49] Qu, H. and Zhao, X, 'Employees' work-family conflict moderating life and job satisfaction', Journal of Business Research, Vol. 65(1), 2012, pp. 22-28.

[50] Ritzenhöfer, L., Brosi, P., Spörrle, M., \& Welpe, I. M, Satisfied with the Job, But Not with the Boss: Leaders' Expressions of Gratitude and Pride Differentially Signal Leader Selfishness, Resulting in Differing Levels of Followers' Satisfaction. Journal of Business Ethics, 158(4), 2019, pp 1185-1202.

[51] Shahidah Ahmad Suhaimi, Siti Azniniza Abdullah, Mafuzah Mohamad, Khairi Safwan Yahya, nor Izzati Razali, \& Wan Nadia Fazira Wan Marzuki, the Effects of Employee Empowerment, Teamwork and Training towards Organizational Commitment among Hotel Employees in Melaka. Global Business \& Management Research, 10(3), 2018, pp 734-742 
An Empirical Study of The Relationships between The Flexible Work Systems (FWS), Organizational Commitment (OC), Work Life Balance (WLB) and Job Satisfaction (JS) For The Teaching Staff In The United Arab Emirates (UAE)

[52] Shockley, K. M., \& Allen, T. D, Investigating the missing link in flexible work arrangement utilization: An individual difference perspective. Journal of Vocational Behavior, 76, 2010, pp 131-142.

[53] Stavrou, E. T., \& Kilaniotis, C, Flexible work and turnover: An empirical investigation across cultures. British Journal of Management, 21(2), 2010, pp 541-554.

[54] Stavrou, E. T., \& Kilaniotis, C, Flexible work and turnover: An empirical investigation across cultures. British Journal of Management, 21(2), 2010, pp 541-554.

[55] Stavrou, E. T., Parry, E., \& Anderson, D, Nonstandard work arrangements and configurations of firm and societal systems. International Journal of Human Resource Management, 26(19), 2015, pp 2412-2433.

[56] Subramaniam. G, Ali. E, Overton. J, “Are Malaysian women interested in flexible working arrangement at workplace?” Business Studies Journal, Volume 2, Special Issue, 2010

[57] Suprihanto, J., Wrangkani, T. D., \& Meliala, A, The relationship between internal marketing and the organizational commitment of doctors and nurses at Mardi Waluyo Hospital, Metro Lampung Indonesia. International Journal of Healthcare Management, 11(2), 2018, pp 7987.

[58] Syrek, C. J., Apostel, E., \& Antoni, C. H, Stress in highly demanding IT jobs: Transformational leadership moderates the impact of time pressure on exhaustion and work-life balance. Journal of Occupational Health Psychology, 18(3), 2013, pp 252-261.

[59] Thompson, R. J., Payne, S. C., \& Taylor, A. B, Applicant Attraction to Flexible Work Arrangements: Separating the Influence of Flextime and Flexplace. Journal of Occupational and Organizational Psychology, 88(4), 2015, pp 726749.https://doi.org/10.1111/joop.12095

[60] Tyler, T. R., \& Blader, S. L, Autonomous vs. comparative status: Must we be better than others to feel good about ourselves? Organizational Behavior and Human Decision Processes, 89, 2002, pp 813-838.

[61] Tipping R, "The Fourth Work Life Balance Employees Survey”. Employees Relations Research Series 122, 2012.

[62] Veen, E., Hurink, J., Schutten, J., \& Uijland, S, A flexible iterative improvement heuristic to support creation of feasible shift rosters in self-rostering. Annals of Operations Research, 239(1), 2016, pp 189-206.

[63] Wheatley, D, Work-Life Balance, Travel-to-Work, and the Dual Career Household, Personnel Review, 41(6), 2012, pp 813-831.

[64] Wayne, J. H., Butts, M. M., Casper, W. J., \& Allen, T. D, In search of balance: A conceptual and empirical integration of multiple meanings of work-family balance. Personnel Psychology, 70, 2017, pp 167-210.

[65] Wayne, J. H., Randel, A. E., \& Stevens, J, The role of identity and work-family support in work-family enrichment and its work-related consequences. Journal of Vocational Behavior, 69, 2006, pp 445-461.

[66] Wilkinson, K., Tomlinson, J., \& Gardiner, J, The perceived fairness of work-life balance policies: A UK case study of solo-living managers and professionals without children. Human Resource Management Journal, 28(2), 2018, pp 325-339.

[67] Wolter, J. S., Bock, D., Mackey, J., Xu, P., \& Smith, J. S, Employee satisfaction trajectories and their effect on customer satisfaction and patronage intentions. Journal of the Academy of Marketing Science, 47(5), 2019, pp 815-836.

[68] Xiao Junru, \& Yi- Jian Huang, the Influence of Teachers' Perceived Organizational Justice on Organizational Citizenship Behavior in Chinese Private Universities: Mediate Role of Job Satisfaction. International Journal of Organizational Innovation, 12(1), 2019, pp 295 303. 
[69] Young, S.J., Sturts, J.R., Ross, C.M. and Kim, K. T, Generational differences and job satisfaction in leisure services, Managing Leisure, Vol. 18(2), 2013, pp.152-170.

[70] Zacher, H., \& Frese, M, Action regulation theory: Foundations, current knowledge, and future directions. In N. Anderson, D. S. Ones, C. Viswesvaran, \& H. K. Sinangil (Eds.), The Sage handbook of industrial, work, \& organizational psychology, Thousand Oaks, CA: Sage. vol. 2 (2nd ed.): 2018, pp 80-102.

[71] V Kandaswamy Sharma, Dr. Beulah Suresh and Dr. S Uma Mageswari, A Conceptual Analysis on Work Life Balance. Journal of Management, 5(4), 2018, pp. 97-100.

[72] Ms. P.Kavitha and Mr. P.Karthikeyan, "A Study on Employee Morale on Job Satisfaction Among the Employees Working in Heavy Industries with Special Reference to Coimbatore Zone", International Journal of Advanced Research in Management (IJARM), Volume 5, Issue 2, March- April (2014), pp. 10-18.

[73] F. Wahidha Begum and Dr. M. Shiek Mohamed. A Study on HRM Practices and its Impact on Job Satisfaction and Organization Performance in BPO Sector, Tiruchirappalli. International Journal of Advanced Research in Management, 7(3), 2016, pp. 01-09.

[74] A. Mary Jansi and Dr. S. Anbazhagan, A Study on Personality Traits of Information Technology (IT) Employees and Job Satisfaction. International Journal of Marketing and Human Resource Management, 8(2), 2017, pp. 01-08.

[75] N. Kamakshi Priya and Dr. M. Kalyana Sundaram, A Study on Relationships Among Job Satisfaction, Organizational Commitment and Turnover Intention In Kolors Healthcare India Pvt ltd, Chennai. International Journal of Advanced Research in Management, 7(1), 2016, pp. 58-71.

[76] Dr K Sathyanarayan and Dr B Latha Lavanya, "Effect of Organizational Commitment, Motivation, Attitude towards Work on Job Satisfaction, Job Performance and Turnover Intention"- VUCA Perspective, Journal of Management, 5(4), 2018, pp. 445-457. 